\title{
Influence of different seed rates on yield contributing traits in wheat varieties
}

\author{
Ghulam Shah Nizamani ${ }^{1,}$, , Shamsuddin Tunio ${ }^{2}$, Umed Ali Buriro², Muhammad Ibrahim Keerio ${ }^{2}$ \\ ${ }^{1}$ Plant Breeding and Genetics, Nuclear Institute of Agriculture (NIA), Tando Jam, Pakistan \\ ${ }^{2}$ Faculty of Crop Production, Sindh Agriculture University, Tando Jam, Pakistan
}

Email address:

nizamanigs@gmail.com (G. S. Nizamani)

To cite this article:

Ghulam Shah Nizamani, Shamsuddin Tunio, Umed Ali Buriro, Muhammad Ibrahim Keerio. Influence of Different Seed Rates on Yield Contributing Traits in Wheat Varieties. Journal of Plant Sciences. Vol. 2, No. 5, 2014, pp. 232-236. doi: 10.11648/j.jps.20140205.23

\begin{abstract}
A series of field experiments were conducted to determine the influence of different seed rates $(100,125 \mathrm{and} 150 \mathrm{~kg}$ $\mathrm{ha}^{-1}$ ) on yield contributing traits of promising wheat varieties viz. Sarsabz, Kiran-95 and TD-1. The maximum germination, spike length and grains spike ${ }^{-1}$ was observed under seed rate of $125 \mathrm{~kg} \mathrm{ha}^{-1}$. The maximum plant population was recorded under seed rate of $150 \mathrm{~kg} \mathrm{ha}^{-1}$ in Kiran-95 and highest grain weight spike ${ }^{-1}$ was noted under seed rate of $100 \mathrm{~kg} \mathrm{ha}^{-1}$ in TD-1 variety. While maximum plant height was observed in Sarsabz under seed rate of $125 \mathrm{~kg} \mathrm{ha}^{-1}$. The maximum 1000 grain weight was observed under seed rate of $100 \mathrm{~kg} \mathrm{ha}^{-1}$ in TD-1; however, highest grain yield was recorded in Kiran-95. The studies about the biological yield revealed that Sarsabz indicated maximum biological yield under seed rate of $125 \mathrm{~kg} \mathrm{ha}^{-1}$ and harvest index in TD-1 under seed rate of $150 \mathrm{~kg} \mathrm{ha}^{-1}$. Based on the findings, it is concluded that the Kiran-95 at the seed rate of $125 \mathrm{~kg} \mathrm{ha}^{-1}$ performed best, followed by TD-1 and Sarsabz which also produced more yield at seed rate of $125 \mathrm{~kg} \mathrm{ha}^{-1}$.
\end{abstract}

Keywords: Seed Rates, Varieties, Yield Attributes, Wheat

\section{Introduction}

Wheat (Triticum aestivum L.) is the most important among all cereals used as a food grain in the world. It ranks first in the world cereal production and is a staple food of about one third of the world's population [1]. It is the basic staple food for most of the population and largest grain source of the country. Its importance is always recognized when formulating agricultural policies. Wheat contributes 12.5 percent to the value added in agriculture and 2.6 percent to Gross Domestic Products (GDP). Wheat is cultivated in an area of 8666 thousand hectares in 2011-12, showing a decrease of 2.6 percent over last year's area of 8901 thousand hectares. The production of 23.5 million tons was estimated during July-March 2011-12. The yield per hectare in 2011-12 posted a negative growth of 4.2 percent as compared to 11 percent growth of last year [2]. With the existing semi-dwarf high yielding varieties, there is enormous potential of obtaining higher crop productivity by adopting production technology such as appropriate seed rates, sowing date, $\mathrm{N}$ and $\mathrm{P}$ rates [3]. Seed rate is considered as an important management factor for improved yield of wheat because it is under the farmer's control in most cropping systems [4]. Due to mild and acceptable flavour, and unique abilities of protein, starch, fat with certain vitamins and minerals, wheat has the exceptional position in the diet of Pakistani people [5].

Pakistan is although, among top wheat producing countries in the world [6], but the average yield of the wheat cultivars grown in the country is much lower than their potential yield [7]. Wheat is planted to a limited extent as a forage crop for livestock and the straw (Bhusa) can be used as a ruminant fodder component or as a construction material for roofing thatch [8]. Joseph et al., [9] concluded that seed rates of 101 to $134 \mathrm{~kg} \mathrm{ha}^{-1}$ are sufficient for high grain yield. Various yield components like tillering, spike length, number of grains spike $^{-1}$ and 1000-grain weight were significantly affected by different varieties and seed rates. The low yield is attributed to many factors viz. sowing patterns, seed rate and varietal potentiality. Yield is the function of many components when that yield relating components have been modified and observed direct influence on the production enhancement viz. optimum seed rate, plant density, climatic condition, soil, sowing time and varieties [10].

Optimum seed rate and suitable cultivars play an important role in achieving its potential yield [11]. Khan [12] reported that that $125 \mathrm{~kg} \mathrm{ha}^{-1}$ is the ideal seed rate to obtain higher grain 
yield. Our objective was to determine the influence of seed rates on yield contributing traits in three high yielding wheat varieties.

\section{Materials and Methods}

\subsection{Plant Materials and Details of Experiments}

A series of field experiments were conducted at Malir Farm, Sindh Agriculture University, Tando Jam, Pakistan, located at $25^{\circ} 25^{\circ} 60^{\circ} \mathrm{N} 68^{\circ} 31^{\circ} 60 \mathrm{E}$ during three consecutive years i.e. 2007-08, 2008-09 and 2009-10; while the laboratory work was conducted at Nuclear Institute of Agriculture, Tando Jam, Pakistan. Three promising spring wheat varieties (Triticum aestivum L.); Sarsabz, Kiran-95 and TD-1 were selected for yield components using different seed rates of 100 125 and $150 \mathrm{~kg} \mathrm{ha}^{-1}$, respectively. The experiments were conducted with three replications in randomized complete block design (Factorial) and plot size of $1.2 \times 2 \mathrm{~m}=2.4 \mathrm{~m}^{2}$ (2m long 4 rows) during 2007-08, 2008-09 and 2009-2010. Ten plants were selected randomly from each treatment for further observations. A good seedbed was obtained by using land preparation operation to facilitate uniform distribution of seed, fertilizer and irrigation water. Sowing was done with single coulter hand drill on $5^{\text {th }}$ to $12^{\text {th }}$ November in Rabi season. The basal dose of NPK fertilizers at the rate of 140-60-30 $\mathrm{kg} \mathrm{ha}^{-1}$ was applied in the form of urea, Di-ammonium phosphate and sulphate of potash, respectively. All $\mathrm{P}, \mathrm{K}$ and half $\mathrm{N}$ were applied at sowing time; while remaining $\mathrm{N}$ was equally divided into two splits and applied at first and third irrigation time. First irrigation was applied 25-30 days after sowing and subsequent irrigations were applied as soil and crop requirement. Weed management practices were carried through manual hand control. The soil analysis of experimental areas showed that soil was clay loam in texture, non saline, $(\mathrm{pH}=7.2-7.6)$, low in organic matter $(0.88-0.96 \%)$, total nitrogen $(0.49-0.57 \%)$, available phosphorus (0.86-165 mg kg-1) and exchangeable potassium $\left(248-278 \mathrm{mg} \mathrm{kg}^{-1}\right)$. The minimum mean temperature $17.75^{\circ} \mathrm{C}$, maximum $32.38^{\circ} \mathrm{C}$ and humidity $69.25 \%$ was recorded during Rabi season 2007-08, 2008-09 and 2009-2010.

\subsection{Determinations of Yield Contributing Traits}

\subsubsection{Plant Height (cm)}

The plant height was measured from ground level to the tip of the flag leaf at harvest through measuring tape in centimeters.

\subsubsection{Plant population $\left(\mathrm{m}^{2}\right)$}

Plant population $\left(\mathrm{m}^{2}\right)$ Number of tillers was counted from $\mathrm{m}^{2}$ area at harvest.

\subsubsection{Spike Length (cm)}

Ten spikes were randomly selected from each treatment. Each spike was measured from the base of spike to the apex to record the spike length in centimeters.

\subsubsection{Grains Spike-1}

Number of grains spike ${ }^{-1}$ was counted from ten randomly selected spikes in each replication at harvest.

\subsubsection{Grain Weight Spike $e^{-1}$}

Weight of grain spike ${ }^{-1}$ (g) was recorded by using digital electronic balance at harvest.

\subsubsection{0-Grain Weight (g)}

1000-grain weight $(\mathrm{g})$ was obtained at random from each treatment and weighed were taken by digital electronic balance.

\subsubsection{Grain Yield ( $\left.\mathrm{ha}^{-1}\right)$}

Wheat bundles of each sub plot were threshed and average grain yield was recorded in $\mathrm{kg} \mathrm{plot}^{-1}$ and then converted into $\mathrm{t}$ $\mathrm{ha}^{-1}$ at harvest.

\subsubsection{Biological Yield $\left(\mathrm{tha}^{-1}\right)$}

Wheat bundles of each sub plot were threshed and average biological yield was recorded in $\mathrm{kg} \mathrm{plot}^{-1}$ and then converted into $\mathrm{tha}^{-1}$ at harvest.

\subsubsection{Harvest Index (\%)}

Harvest index of each treatment was calculated by using formula, harvest index $=$ Grain yield/ biological yield x 100 .

\subsubsection{Harvesting}

The crop was harvested during March, $30^{\text {th }}$ to April $15^{\text {th }}$ 2007-08, 2008-09 and 2009-2010.

\subsection{Statistical Analysis}

The experimental data were recorded and statistically analyzed through Statistix 8.1 computer software (Analytical Software [13], the means were separated using least significant difference (LSD) test. All differences described in the text were significant at the $5 \%$ level of probability.

\section{Results and Discussions}

\subsection{Performance of Varieties}

The results presented in Table 1 revealed that wheat varieties had significant influence on majority of agronomic traits. Among three wheat varieties, Kiran-95 evident better performance $(\mathrm{P}<0.05)$ in germination $(96.49 \%)$, plant population $\left(104.06 \mathrm{~m}^{2}\right)$, spike length $(12.84 \mathrm{~cm})$, grains spike $^{-1}(44.29)$ and grain yield $\left(4.63 \mathrm{tha}^{-1}\right)$. Sarsabz variety of wheat was dominant $(\mathrm{P}<0.05)$ in plant height $(97.05 \mathrm{~cm})$ and biological yield (11.84 $\mathrm{t} \mathrm{ha}^{-1}$ ) than that of Kiran-95 and TD-1. The difference in plant height of the varieties was attributed to difference in their genetic makeup; these findings are agreed with Khokhar et al., [14] and Khaliq et al., [15]. Whereas TD-1 variety of wheat was superior in harvest index (41.41\%), early days to heading (69.72) and maturity (118.34), grain weight $\operatorname{spike}^{-1}(2.74 \mathrm{~g})$ and 1000 grain weight (44.06 g) than that of Kiran-95 (44.00 g) and Sarsabz (41.31 g). However, later two traits were not statistically different $(\mathrm{P}>0.05)$ from that of Kiran-95 (Table 1). The results agreed with Ahloowalia and Maluszynski [16], that high yield potential varieties play a pivotal role in increasing yield $\mathrm{kg} \mathrm{ha}^{-1}$ under optimum growing season. The present moment of global climatic changes, it is important that the new varieties realize their 
production potential under the changing environments in the regions where they have been developed.

Table 1. Performance of different wheat varieties for yield contributing traits.

\begin{tabular}{|c|c|c|c|c|c|}
\hline \multirow{2}{*}{ Plant traits } & \multicolumn{3}{|c|}{ Wheat varieties } & \multirow{2}{*}{$\mathbf{S E} \pm$} & \multirow{2}{*}{$\begin{array}{l}\text { LSD } \\
(5 \%)\end{array}$} \\
\hline & Sarsabz & Kiran-95 & TD-1 & & \\
\hline Germination (\%) & $94.47 \mathrm{~b}$ & $96.49 \mathrm{a}$ & $94.98 \mathrm{~b}$ & 0.2660 & 0.5337 \\
\hline Plant height (cm) & $97.05 \mathrm{a}$ & $89.52 \mathrm{~b}$ & $66.21 \mathrm{c}$ & 0.4760 & 0.9552 \\
\hline Plant population $\left(\mathrm{m}^{2}\right)$ & $101.85 \mathrm{~b}$ & $104.06 \mathrm{a}$ & $98.64 \mathrm{c}$ & 0.7848 & 1.5748 \\
\hline Spike length $(\mathrm{cm})$ & $11.90 \mathrm{~b}$ & $12.84 \mathrm{a}$ & $11.94 \mathrm{~b}$ & 0.1775 & 0.3562 \\
\hline Grains spike $^{-1}$ & $39.52 \mathrm{c}$ & $44.29 \mathrm{a}$ & $43.57 \mathrm{~b}$ & 0.2708 & 0.5433 \\
\hline Grain weight spike $^{-1}(\mathrm{~g})$ & & $2.67 \mathrm{a}$ & & 0.0359 & 0.0721 \\
\hline 1000 grain weight $(\mathrm{g})$ & $41.31 \mathrm{~b}$ & $44.00 \mathrm{a}$ & $44.06 \mathrm{a}$ & 0.1527 & 0.3064 \\
\hline Grain yield $\left(\mathrm{t} \mathrm{ha}^{-1}\right)$ & $4.31 \mathrm{c}$ & $4.63 \mathrm{a}$ & $4.52 \mathrm{~b}$ & 0.0460 & 0.0924 \\
\hline Biological yield $\left(\mathrm{t} \mathrm{ha}^{-1}\right)$ & $11.84 \mathrm{a}$ & $11.54 \mathrm{~b}$ & $10.50 \mathrm{c}$ & 0.0791 & 0.1587 \\
\hline Harvest index (\%) & $35.07 \mathrm{c}$ & $38.53 \mathrm{~b}$ & $41.41 \mathrm{a}$ & 0.3549 & 0.7122 \\
\hline Days to heading & $72.08 \mathrm{~b}$ & $77.04 \mathrm{a}$ & $69.72 \mathrm{c}$ & 0.2110 & 0.4234 \\
\hline Days to maturity & $122.42 \mathrm{~b}$ & $130.11 \mathrm{a}$ & $118.34 \mathrm{c}$ & 0.3156 & 0.6332 \\
\hline
\end{tabular}

Note: In each column, means followed by common letter are not significantly different at 5\% probability level.

\subsection{Influence of Seed Rates}

The result regarding agronomic traits shown in Table 2 reveals that seed rate has significant influence on majority of agronomic traits of wheat. Wheat sown at seed rate of $125 \mathrm{~kg}$ $\mathrm{ha}^{-1}$ significantly $(\mathrm{P}<0.05)$ enhanced the grains spike ${ }^{-1}(42.93)$ compared to that of sown at seed rate of $150 \mathrm{~kg} \mathrm{ha}^{-1}(42.08)$ or $100 \mathrm{~kg} \mathrm{ha}^{-1}$ (42.36). Increase or decrease in seed rate from 125 to 150 or $100 \mathrm{~kg} \mathrm{ha}^{-1}$, respectively did not show any significant variation $(\mathrm{P}>0.05)$ in grains spike $^{-1}$. In spite of germination and harvest index percent appeared relatively better at higher seed rate of $150 \mathrm{~kg} \mathrm{ha}^{-1}$ (95.38 and $38.66 \%$, respectively) than that of $100 \mathrm{~kg} \mathrm{ha}^{-1}$ (95.35 and 38.03, respectively) and $125 \mathrm{~kg}$ $\mathrm{ha}^{-1}$ (95.21 and 38.32, respectively), the differences between them arise statistically non significant $(\mathrm{P}>0.05)$. Similarly the spike length seems to be relatively high at seed rate of $125 \mathrm{~kg}$ $\mathrm{ha}^{-1}(12.32 \mathrm{~cm})$ compared to that of at $150(12.20 \mathrm{~cm})$ and 100 $\mathrm{kg} \mathrm{ha}^{-1}(12.16 \mathrm{~cm})$, they do show statistically non significant differences $(\mathrm{P}>0.05)$. Plant population appeared high at higher seed rate of $150 \mathrm{~kg} \mathrm{ha}^{-1}\left(104.99 \mathrm{~m}^{2}\right)$, followed by $125 \mathrm{~kg} \mathrm{ha}^{-1}$ $\left(101.70 \mathrm{~m}^{2}\right)$ and $100 \mathrm{~kg} \mathrm{ha}^{-1}\left(97.85 \mathrm{~m}^{2}\right)$. Grain weight spike ${ }^{-1}$ and 1000- grain weight $(\mathrm{g})$ were although high at seed rate of 125 (2.67 and $43.67 \mathrm{~g}$, respectively) but statistically similar to that of seed rate $100 \mathrm{~kg} \mathrm{ha}^{-1}$ (2.66 and $43.43 \mathrm{~g}$, respectively). Whereas higher seed rate of $150 \mathrm{~kg} \mathrm{ha}^{-1}$ revealed remarkably least grain weight spike $^{-1}(2.57 \mathrm{~g})$ and 1000 grain weight $(42.27 \mathrm{~g})$ contrast to that of 125 and $100 \mathrm{~kg} \mathrm{ha}^{-1}$ seed rates. Seed rate of $125 \mathrm{~kg} \mathrm{ha}^{-1}$ produced high grain yield $\left(4.54 \mathrm{t} \mathrm{ha}^{-1}\right)$ and biological yield $\left(11.37 \mathrm{tha}^{-1}\right)$, but the high yield for both of these traits seems to be not varied $(\mathrm{P}>0.05)$ from that of 150

$\mathrm{kg} \mathrm{ha}^{-1}$ seed rate (4.50 and $11.35 \mathrm{t} \mathrm{ha}^{-1}$, respectively), but statistically different $(\mathrm{P}<0.05)$ from that of $100 \mathrm{~kg} \mathrm{ha}^{-1}$ seed rate (4.43 and $11.15 \mathrm{tha}^{-1}$, respectively ). Seed rate at a rate of
$100 \mathrm{~kg} \mathrm{ha}^{-1}$ revealed early days to heading (72.32) followed by $125 \mathrm{~kg} \mathrm{ha}^{-1}$ (72.94) and $150 \mathrm{~kg} \mathrm{ha}^{-1}$ (73.57). Although early days to maturity appeared better at seed rate of $100 \mathrm{~kg} \mathrm{ha}^{-1}$ (123.37) than that of seed rate $125 \mathrm{~kg} \mathrm{ha}^{-1}(123.91)$ and $150 \mathrm{~kg}$ $\mathrm{ha}^{-1}(123.59)$, the differences were found to be not significant (Table 2). The findings of this study agree with those reported by Cheema et al., [17] who reported highest wheat grain yield (4293 kg ha ${ }^{-1}$ ) with sowing rate of $125 \mathrm{~kg} \mathrm{ha}^{-1}$. These results also agree with those reported by Mazurek et al. [18] who reported that lower seeding rates had better yield due to vigorous crop growth. The significance of the effects of seed rates on the growth and grain yield of wheat has also been proved by Sikander et al., [19] and the yield and yield components in wheat were affected significantly by seed rate [20]. Similar results were reported by Naseem et al., [21] and Thakur et al., [22] found that wheat was quite responsive to increased seed rate; the highest seed rate produced greater plant population $\mathrm{m}^{2}$; suggesting $125 \mathrm{~kg} \mathrm{ha}^{-1}$ seed rate for achieving good crop growth and higher grain yields.

Table 2. Influence of different seed rates on agronomic traits of wheat

\begin{tabular}{|c|c|c|c|c|c|}
\hline \multirow{2}{*}{ Plant traits } & \multicolumn{3}{|c|}{ Seed rates $\left(\mathrm{kg} \mathrm{ha}^{-1)}\right.$} & \multirow{2}{*}{$\mathbf{S E} \pm$} & \multirow{2}{*}{$\begin{array}{l}\text { LSD } \\
(5 \%)\end{array}$} \\
\hline & 100 & 125 & 150 & & \\
\hline Germination (\%) & $95.35 \mathrm{a}$ & $95.21 \mathrm{a}$ & $95.38 \mathrm{a}$ & 0.2660 & - \\
\hline Plant height $(\mathrm{cm})$ & $85.08 \mathrm{a}$ & $84.39 \mathrm{a}$ & $83.32 \mathrm{~b}$ & 0.4760 & 0.9552 \\
\hline Plant population $\left(\mathrm{m}^{2}\right)$ & $97.85 \mathrm{c}$ & $101.70 \mathrm{~b}$ & $104.99 \mathrm{a}$ & 0.7848 & 1.5748 \\
\hline Spike length (cm) & $12.16 \mathrm{a}$ & $12.32 \mathrm{a}$ & $12.20 \mathrm{a}$ & 0.1775 & - \\
\hline Grains spike $^{-1}$ & $42.36 \mathrm{~b}$ & $42.93 \mathrm{a}$ & $42.08 \mathrm{~b}$ & 0.2708 & 0.5433 \\
\hline Grain weight spike ${ }^{-1}(\mathrm{~g})$ & $2.66 \mathrm{a}$ & $2.67 \mathrm{a}$ & $2.57 \mathrm{~b}$ & 0.0359 & 0.0721 \\
\hline 1000 grain weight (g) & $43.43 \mathrm{a}$ & $43.67 \mathrm{a}$ & $42.27 \mathrm{~b}$ & 0.1527 & 0.3064 \\
\hline Grain yield $\left(\mathrm{t} \mathrm{ha}^{-1}\right)$ & $4.43 \mathrm{~b}$ & $4.54 \mathrm{a}$ & $4.50 \mathrm{ab}$ & 0.0460 & 0.0924 \\
\hline Biological yield $\left(\mathrm{t} \mathrm{ha}^{-1}\right)$ & $11.15 \mathrm{~b}$ & $11.37 \mathrm{a}$ & $11.35 \mathrm{a}$ & 0.0791 & 0.1587 \\
\hline Harvest index (\%) & $38.03 \mathrm{a}$ & $38.32 \mathrm{a}$ & $38.66 \mathrm{a}$ & 0.3549 & - \\
\hline Days to heading & $72.32 \mathrm{c}$ & $72.94 \mathrm{~b}$ & $73.57 \mathrm{a}$ & 0.2110 & 0.4234 \\
\hline Days to maturity & $123.37 \mathrm{a}$ & $123.91 \mathrm{a}$ & $123.59 \mathrm{a}$ & 0.3156 & \\
\hline
\end{tabular}

Note: In each column, means followed by common letter are not significantly different at $5 \%$ probability level.

\subsection{Interactive Influence of Varieties and Seed Rates}

The results presented in Table 3 illustrate the interactive influence of varieties $\mathrm{x}$ seed rates on various agronomic traits of wheat. Result reveals that most of the agronomic traits were affected by interactive effect of varieties $x$ seed rates. The maximum germination $(96.55 \%)$, spike length $(12.89 \mathrm{~cm})$, grains spike ${ }^{-1}(45.05)$, grain yield $\left(4.70 \mathrm{t} \mathrm{ha}^{-1}\right)$ at seed rate of $125 \mathrm{~kg} \mathrm{ha}^{-1}$, plant population $\left(107.07 \mathrm{~m}^{2}\right)$ at seed rate of 150 $\mathrm{kg} \mathrm{ha}^{-1}$ was recorded in Kiran-95, and grain weight spike ${ }^{-1}$ $(2.79 \mathrm{~g})$ and 1000 grain weight $(44.71 \mathrm{~g})$ at seed rate of $100 \mathrm{~kg}$ $\mathrm{ha}^{-1}$ and harvest index (42.07\%) at seed rate of $150 \mathrm{~kg} \mathrm{ha}^{-1}$ in TD-1 variety, while maximum plant height $(97.89 \mathrm{~cm})$ was found at seed rate of $100 \mathrm{~kg} \mathrm{ha}^{-1}$ and biological yield $(12.10 \mathrm{t}$ $\mathrm{ha}^{-1}$ ) at seed rate of $125 \mathrm{~kg} \mathrm{ha}^{-1}$ in Sarsabz. The minimum germination $(94.24 \%)$, plant population $\left(97.80 \mathrm{~m}^{2}\right)$, spike 
length $(11.67 \mathrm{~cm})$, grains spike ${ }^{-1}(39.23)$ and grain yield (4.25 $\left.\mathrm{t} \mathrm{ha}^{-1}\right)$ at seed rate of $100 \mathrm{~kg} \mathrm{ha}^{-1}$, and 1000 grain weight $(41.38$ $\mathrm{g})$, grain weight $\operatorname{spike}^{-1}(2.44 \mathrm{~g})$ and harvest index $(34.79 \%)$ at seed rate of $150 \mathrm{~kg} \mathrm{ha}^{-1}$ were obtained in Sarsabz variety, while minimum biological yield (10.39 $\left.\mathrm{t} \mathrm{ha}^{-1}\right)$ and early days to heading (69.36 days) at seed rate of $100 \mathrm{~kg} \mathrm{ha}^{-1}$, and plant height $(65.16 \mathrm{~cm})$ and days to maturity (117.57) at seed rate of $150 \mathrm{~kg} \mathrm{ha}^{-1}$ was observed in TD-1. However, crop sown at a seed rate of $125 \mathrm{~kg} \mathrm{ha}^{-1}$ increased the spike length and grain yield and other parameters. The difference in plant height of the varieties was attributed to difference in their genetic makeup $[14,15]$. Similar results were reported by Naseem et al., [21] and Thakur et al., [22] found that wheat was quite responsive to increased seed rate; the highest seed rate produced greater plant population $\mathrm{m}^{2}$; suggesting $125 \mathrm{~kg} \mathrm{ha}^{-1}$ seed rate for achieving good crop growth and higher grain yields.

Table 3. Interactive influence of varieties $x$ seed rates on various agronomic traits of wheat

\begin{tabular}{|c|c|c|c|c|c|c|c|}
\hline Varieties & $\begin{array}{l}\text { Seed rates } \\
\left(\mathrm{kg} \mathrm{ha}^{-1}\right)\end{array}$ & $\begin{array}{l}\text { Germination } \\
(\%)\end{array}$ & Plant height (cm) & Plant Population $\left(\mathrm{m}^{2}\right)$ & Spike length (cm) & $\begin{array}{l}\text { Grains } \\
\text { spike }^{-1}\end{array}$ & Grain weight spike $^{-1}$ (g) \\
\hline \multirow{3}{*}{ Sarsabz } & 100 & $94.24 \mathrm{c}$ & $97.89 \mathrm{a}$ & $97.80 \mathrm{e}$ & $11.67 \mathrm{~b}$ & $39.23 \mathrm{c}$ & $2.49 \mathrm{~cd}$ \\
\hline & 125 & $94.49 \mathrm{bc}$ & $97.11 \mathrm{ab}$ & $101.79 \mathrm{bc}$ & $11.99 \mathrm{~b}$ & $39.99 \mathrm{c}$ & $2.52 \mathrm{~cd}$ \\
\hline & 150 & $94.69 \mathrm{bc}$ & $96.16 \mathrm{~b}$ & $105.96 \mathrm{a}$ & $12.02 \mathrm{~b}$ & $39.33 \mathrm{c}$ & $2.44 \mathrm{~d}$ \\
\hline \multirow{3}{*}{ Kiran-95 } & 100 & $96.47 \mathrm{a}$ & $90.20 \mathrm{c}$ & $100.73 \mathrm{~cd}$ & $12.83 \mathrm{a}$ & $44.01 \mathrm{~b}$ & $2.69 \mathrm{ab}$ \\
\hline & 125 & $96.55 \mathrm{a}$ & $89.73 \mathrm{c}$ & $104.36 \mathrm{ab}$ & $12.89 \mathrm{a}$ & $45.05 \mathrm{a}$ & $2.72 \mathrm{ab}$ \\
\hline & 150 & $96.44 \mathrm{a}$ & $88.63 \mathrm{c}$ & $107.07 \mathrm{a}$ & $12.80 \mathrm{a}$ & $43.80 \mathrm{~b}$ & $2.60 \mathrm{bc}$ \\
\hline \multirow[t]{2}{*}{ TD-1 } & 125 & $94.58 \mathrm{bc}$ & $66.32 \mathrm{de}$ & 98.95 de & $12.07 \mathrm{~b}$ & $43.74 \mathrm{~b}$ & $2.77 \mathrm{a}$ \\
\hline & 150 & $95.01 \mathrm{bc}$ & $65.16 \mathrm{e}$ & $101.93 \mathrm{bc}$ & $11.78 \mathrm{~b}$ & $43.12 b$ & $2.67 \mathrm{ab}$ \\
\hline $\mathrm{SE} \pm$ & & 0.4607 & 0.8245 & 1.3593 & 0.3074 & 0.469 & 0.0682 \\
\hline LSD (5\%) & & - & - & - & - & - & - \\
\hline
\end{tabular}

Table 3. Continued

\begin{tabular}{|c|c|c|c|c|c|c|}
\hline \multirow{3}{*}{ Varieties } & \multirow{3}{*}{1000 grain weight $(\mathrm{g})$} & Grain yield & Biological yield & Harvest & Days to & Days to \\
\hline & & \multirow{2}{*}{$\left(\mathrm{t} \mathrm{ha} \mathrm{a}^{-1}\right)$} & \multirow{2}{*}{$\left(\mathrm{t} \mathrm{ha}^{-1}\right)$} & index & \multirow{2}{*}{ heading } & \multirow{2}{*}{ maturity } \\
\hline & & & & $(\%)$ & & \\
\hline \multirow{3}{*}{ Sarsabz } & $41.38 \mathrm{~d}$ & $4.25 \mathrm{e}$ & $11.66 \mathrm{bc}$ & $35.06 \mathrm{~d}$ & $71.43 \mathrm{~d}$ & $121.89 \mathrm{~d}$ \\
\hline & $42.12 \mathrm{c}$ & $4.34 \mathrm{de}$ & $12.01 \mathrm{a}$ & $35.35 \mathrm{~d}$ & $71.90 \mathrm{~d}$ & $122.30 \mathrm{~cd}$ \\
\hline & $40.44 \mathrm{e}$ & $4.36 \mathrm{de}$ & $11.85 \mathrm{ab}$ & $34.79 \mathrm{~d}$ & $72.89 \mathrm{c}$ & $123.06 \mathrm{c}$ \\
\hline \multirow[b]{2}{*}{ Kiran-95 } & $44.20 \mathrm{a}$ & $4.52 \mathrm{bc}$ & $11.40 \mathrm{c}$ & $37.77 \mathrm{c}$ & $76.18 \mathrm{~b}$ & $129.13 \mathrm{~b}$ \\
\hline & $44.56 \mathrm{a}$ & $4.70 \mathrm{a}$ & $11.59 \mathrm{bc}$ & $38.73 \mathrm{bc}$ & $77.31 \mathrm{a}$ & $131.06 \mathrm{a}$ \\
\hline \multirow{3}{*}{ TD-1 } & $44.71 \mathrm{a}$ & $4.52 \mathrm{bc}$ & $10.39 \mathrm{~d}$ & $41.28 \mathrm{a}$ & $69.36 \mathrm{f}$ & $119.11 \mathrm{e}$ \\
\hline & $44.34 \mathrm{a}$ & $4.57 \mathrm{a}-\mathrm{c}$ & $10.51 \mathrm{~d}$ & $40.88 \mathrm{a}$ & $69.59 \mathrm{ef}$ & $118.35 \mathrm{ef}$ \\
\hline & $43.14 \mathrm{~b}$ & $4.47 \mathrm{~cd}$ & $10.58 \mathrm{~d}$ & $42.07 \mathrm{a}$ & $70.21 \mathrm{e}$ & $117.57 \mathrm{f}$ \\
\hline $\mathrm{SE} \pm$ & 0.2645 & 0.0797 & 0.137 & 0.6147 & 0.3655 & 0.5466 \\
\hline $\operatorname{LSD}(5 \%)$ & - & - & - & - & - & 1.0968 \\
\hline
\end{tabular}

Note: In each column, means followed by common letter are not significantly different at 5\% probability level.

\section{Conclusion}

It is concluded that present research showd that wheat sown under seed rate of $125 \mathrm{~kg}$ ha-1 had better growth and yield parameters. The interactive influence of Kiran-95 x $125 \mathrm{~kg}$ ha-1 seed rate was found superior for achieving higher grain yield, followed by TD-1 and Sarsabz which also produced more grain yield.

\section{Acknowledgements}

We thank to Dr. Muhammad Ibrahim Khaskheli for his invaluable technical help and support.

\section{References}

[1] H. Iqtidar, Khan M.A. and Khan H. Effect of seed rates on the agro-physiological traits of wheat. Sarhad J. Agric. vol. 26, pp
169-176, 2010.

[2] GOP. Economic Survey of Pakistan. 2011-2012. Ministry of Food, Agriculture and Livestock, Government of Pakistan, Statistics Division (Economic Wing), Islamabad, 2011-12, p. 21.

[3] C.A, Campbell, F. Selles, R.P. Zentner, J.G. Mcleod, and F.B. Dyck. Effect of seeding date, rate and depth on winter wheat grown on environmental fallow in South Western Saskatchewan. Can. J. Plant Sci., vol. 71, pp. 51-61, 1991.

[4] G.A. Slafer and H.E. Satorre. Plant density and distribution as modifiers of growth and yield. In E.H. Satorre and G.A. Slafer (ed.) Wheat Ecology and physiology of yield determination. Food Products Press, New York. 1999, pp. 141-159.

[5] A. Soomro and F.C. Oad. Yield potentials of wheat genotypes under different planting times. J. Applied Sci., vol. 2, 713-714, 2002.

[6] I.A. Khan, A. Ihsanullah, Jan. F.H. Taj, and N. Khan. Effect of sowing dates on yield and yield components of Mash bean. Asian J. P1. Sci. vol. 1, pp. 622-624, 2002. 
[7] M.A. Arain, M. A. Sial, M.A. Shamadad Khanzada, M.H. Naqvi, M.U. Dahot and N.A. Nizamani. Yield and quality parameters by sowing dates and high temperature stress. Pak. J. Bot., vol. 37, pp. 575-584, 2005.

[8] Kingfisher. The Kingfisher History Encyclopedia. Kingfisher Publications. 2004, pp. 8.

[9] K.D. Joseph, M.M.S.B Alley, D.L. Brann, and W.D. Gravelle. Row spacing and seeding rate effects on yield and yield components of soft red winter wheat. Agron. J., vol. 77, pp. 211-214, 1985.

[10] M.A. Arain, M.A. Sial, M.A. Javed and M.A. Rajput. Genotype environment for grain yield in bread wheat. Proc. Pakistan Acad. Sci. vol. 38, pp. 41-46, 2001.

[11] K. T. Sikander, H. Imtiaz., M. Asif, M.Y. Mujahid, S. Muhammad, M. Qamar and M. Asim. Performance of different wheat varieties/lines as affected by different planting dates and seeding rates under high rainfall area of Potohar. Pak. J. Agri. Sci., vol. 46, pp. 102-106, 2009.

[12] A.M. Khan. Effect of seeding rates and nitrogen levels on growth and yield of wheat. M.Sc. Thesis, Univ. Agri. Faisalabad, Pakistan, 1996.

[13] Analytical Software, 2005. Statistix 8.1 user's manual, Tallahassee, FL.

[14] M.S. Khokhar, M.S. Sheikh, M. Siddique and M.S. Nazir. Effect of different seeding densities and nitrogen levels on the yields of two whet genotypes. Pakistan J. Agric., vol. 6, pp. 150-152, 1985.
[15] A. M. Khaliq, Iqbal and S.M.A. Basra. Optimisation of seeding densities and nitrogen application in wheat cv. Inqalab-91 under Faisalabad conditions. Int. J. Agric. Biol., vol. 1, pp. 241-243, 1999.

[16] B.S. Ahloowalia and M. Maluszynski. Induced mutations - A new paradigm in plant. Euphytica, vol. 118, pp. 167-173, 2001.

[17] M.S. Cheema, M. Akhtar and A. Liaquat. Effect of seed rate and NPK fertilizer on growth and yield of wheat variety Punjnad. Pak. J. Agron., vol. 2, 185-189, 2003.

[18] J. Mazurek and A. Sabat. Effect of sowing rate and nitrogen fertilizer application on yield of some triticale cultivars. Pamie hook tnik Pulawski. vol. 83, 85-93, 1984.

[19] K. Sikander, I. Hussain K. Tanveer, M. Sohail, N.S. Kissana and S.G. Abbas. Effects of different planting methods on yield and yield components of wheat. Asian J. Plant Sci., vol. 2, pp. 811-813, 2003.

[20] E. Hameed, W.A. Shah, A. A. Shad, F.H. Taj and J. Bakht. Yield and yield components of wheat as affected by different planting dates, seed rate and nitrogen levels. Asian J. Plant Sci. vol. 1, pp. 502-506, 2002.

[21] K. Naseem, A. R.H. Qureshi, J. Akhtar and M.A. Masood. Screening of wheat (Triticum aestivum L.) genotypes against salinity in solution culture. Pakistan J. Agric. Sci., 37, pp. 1-6, 2002.

[22] S.S. Thakur, I.S. Pandev. S.J. Singh and S.S. Mishr. Effect of seed rate and row spacing on late sown wheat in alluvial calcareous soil. J. Res. Bisra Agric. Univ. vol. 2, pp. 123-125, 1996 